\title{
FILIPINAS, FIN DE SIGLO: IMÁGENES Y REALIDAD
}

POR

\author{
MARÍA DOLORES ELIZALDE
}

Centro de Estudios Históricos, CSIC

El presente artículo pretende ofrecer una imagen de las Filipinas de fin de siglo, diferente de la transmitida por la historiografia tradicional y por la viñetas y caricaturas de la época. Frente a los estereotipos de unas islas atrasadas, incapaces del autogobierno, habitadas por salvajes a los que había que civilizar, se impone una realidad definida por el gobierno colonial de España, en pleno proceso de redefinición; por el afianzamiento de una burguesía ilustrada filipina, la pujanza de una clase campesina y obrera, la fuerza de un movimiento de afirmación nacional, y el desarrollo de una economía agroexportadora en pleno crecimiento; $y$ por la presencia de fuertes intereses internacionales que hay que entender insertos en la marea de expansión colonial y reparto de mercados y territorios ultramarinos; intereses internacionales de los que se da cuenta a través de un análisis de comercio, inversiones y presencia diplomática de las grandes potencias en las Filipinas de fin de siglo.

\section{IMÁGENES DE UN PAÍS EN FORMACIÓN}

En 1898, la imagen de Filipinas que se extendió en los Estados Unidos fue la de un país atrasado, lastrado por la administración colonial española, calificada de autoritaria, ineficaz y corrupta; donde las órdenes religiosas tenían un peso tal que impedían el desarrollo de la sociedad y coartaban cualquier brote de libertad; la economía de las islas, independientemente de sus posibilidades, respondía al estado del archipiélago ${ }^{1}$.

1 El mejor ejemplo de tal visión es el informe preparado por la Comisión Filipina creada por el Gobierno de los Estados Unidos para conocer el estado de las islas al hacerse cargo de su gobierno: Report of the Philippine Commission, Washington, Government Printing Office, 1901, 4 vols. Esta obra tiene un interés evidente y es una fuente de información 
La idea de los habitantes de las islas tampoco era muy reconfortante. La mentalidad norteamericana no había escapado al influjo de las teorías del darwinismo social tan extendidas en la época, que defendían la superioridad de unas razas sobre otras. En tal sentido estaban convencidos de la preponderancia racial de los anglosajones. En ese esquema los españoles ocupaban un lugar inferior, y aún más atrasados estaban los filipinos ${ }^{2}$. La iconografía norteamericana de la época representaba a los naturales de Filipinas como salvajes, inferiores en inteligencia, o también, a menudo, como niños en un estadio inferior de desarrollo, y por tanto incapaces del autogobierno ${ }^{3}$. No obstante, este pueblo podría aprender y beneficiarse de las enseñanzas de los norteamericanos. Eran frecuentes las viñetas de filipinos asistiendo a una escuela en la que los maestros eran los estadounidenses, respondiendo al discurso moral sobre los beneficios del progreso, de la igualdad y de la democracia que encarnaban los Estados Unidos, y sobre el deber de su gobierno de propagar esos beneficios sobre otros pueblos más atrasados ${ }^{4}$.

La imagen de Filipinas en España tampoco era favorable. El atraso de las islas era comunmente aceptado, hasta el punto de que tal situación era la que justificaba la desigualdad legal, la falta de derechos representativos, y la ausencia de reformas y libertades en el archipiélago. Sin embargo, la realidad de las Filipinas a fines del siglo XIX no se ajustaba a tales estereotipos. Era mucho más rica y compleja. En las últimas décadas de la pasada centuria la situación

muy valiosa, pero conviene leerla con objetividad, entendiendo el interés político por magnificar los errores del gobierno español y por resaltar los beneficios de la administración norteamericana para las islas, en un evidente esfuerzo para justificar la intervención de los Estados Unidos en Filipinas.

2 Gerald F. LINDERMAN, The Mirror of War. American Society and the Spanish American War, Ann Arbor, 1974. Julián COMPANYS, La prensa amarilla norteamericana en 1898, Madrid, 1998. Rafael SANCHEZ MANTERO, "El 98 y la imagen de España en Estados Unidos", Revista de Occidente, $\mathrm{n}^{\circ}$ 202, Marzo 1998, pp. 294-309.

3 Nuevamente conviene resaltar el interés político de esta imagen: los filipinos, incapaces del autogobierno. Esta idea fue defendida tanto por españoles como por norteamericanos en un esfuerzo por explicar la situación colonial del archipiélago.

4 En la década de 1890 el pueblo americano estaba orgullosos de su productividad agrícola e industrial, de su avanzada tecnología, de su capacidad de consumo. Con optimismo, pensaban que otros pueblos podrían alcanzar el mismo grado de desarrollo si imitaban el modelo americano, si aceptaban el desarrollo de las empresas privadas y abrían las puertas al comercio y a las inversiones. Creían que era deber del gobierno americano propagar esas ideas. Emily RosENBERG, Spreading the American Dream: American Economic and Cultural Expansión, 1890-1945, New York, 1982.

R. I., $1998, \mathrm{n}^{\circ} 213$ 
de las islas quedaba definida por el cruce de tres coyunturas: 1- el gobierno colonial de España; 2- la pujanza de una nueva clase ilustrada filipina y de una burguesía fundamentalmente agrícola que impulsaban el desarrollo de su país, junto con la fuerza creciente de un movimiento nacionalista plural; 3- los fuertes intereses internacionales asentados en el archipiélago. Sobre esas tres circunstancias se superpuso el interés norteamericano por Filipinas, súbitamente manifestado durante la guerra hispano-nortemericana de 1898.

\section{EL GOBIERNO ESPAÑOL}

La primera circunstancia que llama la atención en el gobierno español de Filipinas de fines del siglo XIX es su peculiar situación jurídica. En el artículo 89 de la Constitución de 1876, que otorgaba marco legal al régimen político de la Restauración, las Filipinas quedaban definidas como provincia ultramarina, sujeta a leyes especiales. Provincia española, pues, pero, dadas sus peculiares circunstancias, privada de los mismos derechos que las demás provincias españolas, incluidas las islas de las Antillas. El ideal era asimilista, extender a aquellos archipiélagos las mismas leyes y costumbres que en la Península. Pero la realidad aconsejaba la diferenciación, según las autoridades españolas de la época. La igualdad quedaba por tanto desvirtuada y se llegaba al trato de colonia, gobernada por reales decretos que no pasaban por Cortes, en la que los nativos de las islas no gozaban de los mismos derechos que los peninsulares y no tenían representación parlamentaria. Existía, además, una evidente intención de explotación económica en favor de la Metrópoli 5 .

\footnotetext{
5 Manuel Azcárraga, experto conocedor de Filipinas como antiguo gobernador civil de Manila, justificaba en las Cortes que las Filipinas tuvieran un tratamiento legal diferente al de las demás provincias basándose en que "aquella colonia se puede considerar aún en su período de educación. El proceso de asimilación no está adelantado y los derechos políticos que tienen en Cuba y Puerto Rico de ninguna manera pueden aplicarse a las islas Filipinas, ni en forma de leyes especiales, porque si hoy los establecierais, no sería en beneficio de los cinco o seis millones de indígenas, que son la verdadera población de aquellas islas, porque éstos no los ejercerían, porque no los necesitan ni los comprenden", (Diario de Sesiones, 24 Mayo 1876)

Victor Balaguer, ex-ministro de Ultramar, también defendía la excepcionalidad de las Filipinas en el conjunto español. Se declaraba partidario del asimilismo, pero consideraba necesaria una legislación especial para Filipinas hecha en Cortes. "Si hay algún país en el
} 
El gobierno de las islas se caracterizó también por estar en manos de autoridades militares. El Gobernador General de las islas era el representante de la nación, delegado de los ministerios de Ultramar, Guerra, Marina y Estado. Su autoridad se extendía a todo cuanto conducía al mantenimiento de la integridad del territorio, la observancia y ejecución de las leyes, la conservación del orden público y la protección de las personas y propiedades. Tenía el mando superior del Ejército y la Armada en las islas y todos las demás cargos del archipiélago quedaban subordinados a su autoridad ${ }^{6}$. Estaba auxiliado por una Junta de Autoridades, de carácter meramente consultivo, con lo cual su poder en el plano político y militar era amplísimo. El archipiélago estaba dividido en distritos, administrados por gobernadores civiles, militares y político-militares, que se encargaban de los asuntos gubernativos, económicos y militares. Dependían directamente del Gobernador General, aunque debían dar cuenta de sus actividades económicas al Intendente General de Hacienda y de las cuestiones de administración local y fomento al Director de Administración Civil. De la justicia en las islas se ocupaban la Audiencia de Manila y la Audiencia de Cebú, representadas en el archipiélago

\begin{abstract}
mundo que necesite de leyes especiales, especialísimas, confieso que es de seguro Filipinas", (Diario de Sesiones, 24 Mayo 1876).

En otra discusión en Cortes, el ministro de Fomento con Cánovas, Fermín Lasala, definía la ambigua posición de muchos políticos españoles respecto a la situación legal de Filipinas: "No se ha creído hasta ahora por los diversos gobiernos que ha habido que lo relativo a Filipinas estuviera en el mismo caso que lo relativo a Cuba y Puerto Rico. Siempre se ha interpretado que Cuba y Puerto Rico eran provincias españolas, en las cuales con tales o cuales modificaciones podían y debían regir las leyes constitucionales; pero hasta ahora que yo sepa, nadie ha creído que artículo ninguno de la Constitución pudiera regir en Filipinas; se ha creído generalmente que aquel Archipiélago formaba parte del imperio colonial, pero que no era propiamente provincia española y bajo ese punto de vista se han resuelto las cuestiones relativas a Filipinas", (Diario de Sesiones, 18 Marzo 1880).

Manuel Becerra, ministro de Ultramar en el gobierno liberal de Sagasta, y puso en marcha un amplio plan de reformas para Filipinas, en el preámbulo de la Real Orden de 18 de Enero de 1889 que daba carta legal a dichas medidas se refería a la tendencia asimilista pretendida por los sucesivos gobiernos de la nación con respecto a Filipinas. Pero inmediatamente añadía la imposibilidad de llevarla a cabo hasta sus últimas consecuencias, ya que "no es posible la identidad política entre países que constituyen una sola nación soberana cuando la distancia, el clima, el carácter de sus gentes y la diversidad de sus costumbres, de sus necesidades y de sus medios, marcan, como sucede entre la Península y las islas Filipinas, grandes diferencias", (Real Orden de 18 de Enero de 1889).

6 Real Decreto de 8 Noviembre 1878.
\end{abstract}

R. I., 1998, n. $^{\circ} 213$ 
por los alcaldes mayores y por los jueces de paz, estableciéndose así una separación de poderes?.

La Marina tenía un gran peso en las islas, en tanto se encargaba de la defensa y de las comunicaciones entre los distintos pueblos e islas del archipiélago, relacionados fundamentalmente por mar. A pesar de los esfuerzos de este ramo, y debido a su falta de medios, existió en las islas una debilidad defensiva notable, que impidió un control efectivo sobre la totalidad del archipiélago. Esta circunstancia permitió que en numerosos puntos se desarrollaran unas élites nativas sin intereses en común con los españoles, o que en determinadas áreas permanecieran focos de resistencia a la autoridad colonial, escasamente reconocida.

En el gobierno de las islas existió, en las últimas décadas del XIX, una dicotomía importante entre los partidarios de introducir reformas, de modernizar, y aquellos que apoyaban a ultranza la defensa de la situación, el mantenimiento del statu quo. La tensión entre estas dos fuerzas fue contínua, pero a pesar de que la administración fue mejorándose progresivamente en pequeños puntos, y de que se intentaron reformas importantes, como las propuestas por Manuel Becerra y por Antonio Maura, prevaleció la opción más conservadora $^{8}$. Ante el temor de que medidas renovadoras pudieran propiciar amenazas a la soberanía o a los intereses españoles, se prefirió proteger, consolidar, reforzar, y no cambiar en lo fundamental.

Las órdenes religiosas tuvieron un peso considerable en la vida y en la organización de las islas, debido a dos circunstancias: fueron frecuentemente los representantes de la administración colonial en aquellos puntos o pueblos donde eran los únicos españoles, ejerciendo una labor de interlocutores entre el gobierno y los indígenas; desempempeñaron funciones muy amplias, que abarcaban el campo religioso, el educativo, y el económico; fueron, además, grandes

7 Julia CELDRÁN RUANO, Instituciones hispano-filipinas del siglo XIX, Madrid, 1994. NP. CUSHNER, Spain in the Philippines: From Conquest to Revolution, Quezon City, 1971. José ARCILla, An Introduction to Philippine History, Quezon City, 1973. Renato ConsTANTINO, A history of the Philippines: from the Spanish Colonization to the Second World War, New York, 1975. Antonio MolinA, Historia de Filipinas, Madrid, 1984, 2 vols.

8 Antoni MARImon, La política colonial d'Antoni Maura, Palma, 1994; "Las reformas de Antonio Maura, ministro de Ultramar (1892-1894), en las islas Filipinas", en Juan Pablo Fusi y Antonio Niño, (eds.), Antes del Desastre: Orígenes y Antecedentes de la crisis del 98, Madrid, 1996, pp. 243-251. 
propietarias de tierras rústicas y de suelo urbano, y participaron en actividades comerciales, ejerciendo incluso de prestamistas 9 .

Otra peculiaridad notable del gobierno de Filipinas fue el mantenimiento de la vida política local en manos de los propios indígenas. Las élites filipinas dominantes se convirtieron en los intermediarios entre las autoridades españolas y la población nativa, favorecidos por la propia administración colonial. Los antiguos "datos" fueron nombrados cabezas de barangays y encargados del gobierno local, del control orden público y del cobro de los tributos ${ }^{10}$.

La actividad económica española en Filipinas, fue al igual que constante, reducida, siempre por debajo de las posibilidades de las islas; circunstancia que se agravaba por la escasa presencia de peninsulares en el archipiélago. Sin embargo, a partir de 1880 se fue implantando un nuevo modelo económico. Para salir de la crisis en la que estaban sumidas las islas, se decidió acabar el estanco del tabaco y de los alcoholes indígenas sobre el que descansaba la economía de las islas desde fines del siglo XVIII ${ }^{11}$. El estanco se había consolidado sobre todo a partir de la independencia de las colonias americanas. Esta supuso para Filipinas la desaparición del comercio del Galeón de Manila que había sido el gran aliciente de la economía agraria exportadora que había caracterizado a las islas hasta ese momento ${ }^{12}$, y también el fin de la llegada del "situado" procedente de Nueva España ${ }^{13}$. El sistema económico basado en los estancos había funcionado con eficacia hasta mediados del siglo XIX, fecha a partir de la cual se que intensificando su crisis hasta que fue inevita-

9 Dennis Roth, The Friar Estates of the Philippines, Alburquerque, 1977. Pedro BORGES, Historia de la Iglesia en Hispanoamérica y Filipinas, (siglos XV-XIX), Madrid, 1992, ver en esta obra los artículos de Isacio RoDRíGUEZ, "Filipinas: la organización de la Iglesia", pp. 704-720, y de Antolín ABAD, "Filipinas, labor misional y pastoral", pp. 721-757.

10 Luis Angel SANCHEZ, Las principalías indígenas y la administración española en Filipinas, Madrid, 1991. John LARKIN, The Pampangans: Colonial Society in a Philippine Province, Berkeley, 1972.

11 Josep M. FrADERA, Filipinas: la colonia más peculiar. La hacienda pública en la definición de la política colonial, 1762-1868, Madrid, CSIC, (en prensa). Tengo que agradecer la consulta de esta obra aún inédita a la generosidad del autor. Sobre este mismo tema se pueden consultar también, Josep M. FRADERA, "El estanco de tabaco y la reforma de la hacienda filipina, 1760-1860"; Hacienda Pública Española, Monografía, 1996, pp. 85-98; "Fiscalidad y ruptura política en Filipinas, 1864-1888" (en Prensa).

12 William SCHURZ, The Manila Galleon, New York, 1939 (traducción española en 1992). Tokio, 1981.

13 LE. BAuzon, Deficit Goverment: México and the Philippine Situado (1606-1804), 
ble su desaparición. Además, en 1869 se abrió el Canal de Suez, lo cual facilitó enormente las comunicaciones con el Extremo Oriente. Y desde finales de los años sesenta, la crisis en las Antillas hizo que los inversores españoles miraran con nuevo interés a las posesiones españolas en el Pacífico.

La suma de estas circunstancias provocó que en Filipinas se potenciara un nuevo sistema económico basado en una mayor incentivación de la inversión española, - pública y privada-, en la economía de las islas. Además se aplicó una política proteccionista que primó la entrada de productos peninsulares en Filipinas. Eso hizo que las importaciones españolas a las islas aumentaran del $7.3 \%$ en 1881 , al $32.1 \%$ en 1893, convirtiéndose así en el primer país importador de mercancias. También se tradujo en la creación de nuevas empresas, la más importante de las cuales fue la Compañía General de Tabacos de Filipinas ${ }^{14}$, e igualmente en una mayor presencia de españoles en las islas, ejemplificada por la compañía de los hermanos Muñoz de Bustillo, floreciente empresa dedicada a la exportación de ábaca en Albay. Al tiempo el comercio internacional, especialmente de exportación, mantuvo, su ritmo de crecimiento, lo cual generó importantes beneficios gracias a las rentas de aduanas. También se obtuvieron beneficios a través de los impuestos a los que estaba sujeta la población de las islas.

De esta forma, tras la profunda crisis sufrida en los años setenta y una vez cerrado el ciclo en el que la economía de las islas había estado basada fundamentalmente en el estanco del tabaco y los alcoholes indígenas, gracias a la implantación de este nuevo sistema económico, en 1897, un año antes de la pérdida de las islas, Filipinas había conseguido ser nuevamente, un territorio rentable y autosuficiente, con un gran porvenir y muchas expectativas ante su futuro.

\section{FILIPINAS, UNA NACIÓN EN MARCHA}

A lo largo del siglo XIX se definieron los perfiles de una nueva sociedad filipina. No era aquella una nación de "niños en forma-

\footnotetext{
14 Josep María Delgado, "Bajo dos banderas (1881-1910). Sobre cómo sobrevivió la Compañía General de Filipinas al Desastre del 98", en Consuelo NARANJo, Miguel Angel PUIG-SAMPER y Luis Miguel GarCía MORA, (eds.), La nación soñada: Cuba, Puerto Rico Y Filipinas ante el 98, Madrid, 1996, pp. 293-303.
} 
ción", ni de "salvajes por civilizar". Era un país con unas élites desarrolladas, en la que emergían nuevas clases sociales, y comenzaba a formarse, desde una profunda diversidad, una conciencia nacional.

Desde fines del XVIII se había ido consolidando una élite filipina de hacendados y comerciantes, que adquirieron una importancia económica y política creciente. Se dedicaron fundamentalmente a una agricultura orientada a la exportación. Dadas las peculiaridades de la economía en Filipinas, en donde la metrópoli no era el motor fundamental de las actividades económicas, ni controlaba sus mecanismos de acción, establecieron sus relaciones comerciales no con comerciantes españoles que ejercieran de intermediarios entre la colonia y el exterior, sino directamente con empresas británicas, alemanas y norteamericanas, o con comerciantes chinos. Su mercado no era pues, España, sino otras potencias con las que comerciaban directamente. Esa situación estuvo en el origen de la divergencia de intereses entre filipinos y españoles. Esta élite filipina no era un grupo homogéneo, pues a menudo sus intereses diferían dependiendo de su origen territorial, o según su actividad fueran las plantaciones de azúcar de Pampanga o Negros, los cultivos de arroz de Luzón, la recogida de ábaca en Kabikolam, o de otros productos y otras áreas que requerían necesidades y actuaciones distintas. A pesar de esas diferencias, se fueron definiendo como un nuevo grupo social, económico y político, no uniforme, pero, cada uno desde su posición, impulsor de cambios en Filipinas y por tanto fundamental en la forja de la nación ${ }^{15}$.

Esos grupos económicamente poderosos se interesaron además en la formación de instituciones económicas como el Banco Español Filipino de Isabel II, fundado en 1851, impulsado por las autoridades coloniales españolas, pero en el que ya estaban involucrados filipinos notables como Fernando Aguirre y José María Tuason. En 1869, respondiendo a influencias liberales, el banco cambió de nombre, adoptando el de Banco Español Filipino, y lo que es más importan-

15 AW. MCCOY y E.C. de Jesus, Philippine Social History: Global Trade and Local Transformations. Quezon city, 1991. Ed. de JESÚS, The Tobacco Monopoly in the Philippines. Bureaucreatic Enterprise and Social Change, 1766-1880, Quezon City, 1980. John A. LARKIN, [10], y Sugar and the Origins of Modern Philippine Society, Berkeley, 1993. Norman OwEN, Prosperity without Progress. Manila Hemp and Material Life in the Colonial Philippines, Berkeley, 1984.

R. I., $1998, \mathrm{n}^{\circ} 213$ 
te, consiguió una nueva autonomía administrativa que facilitó la incorporación de filipinos ${ }^{16}$.

A la par de estos grupos, a menudo entrelazados, se fue formando también una clase ilustrada, educada en universidades filipinas, que frecuentemente completaba su formación en instituciones europeas o americanas. Este grupo fue esencial en la formación de una conciencia nacional filipina. A través de sus escritos definieron los rasgos esenciales de esa identidad, criticaron sus defectos e impulsaron una regeneración, en aras de la construcción nacional que paulatinamente fue llevando a la reclamación del autogobierno y la independencia ${ }^{17}$.

También fue cobrando importancia una clase de campesinos filipinos, menos potentes esconómicamente, pero igualmente concienciados de la necesidad de una reivindicación de sus derechos frente a la administración colonial y frente a la posición que ocupaban las órdenes religiosas en las islas como propietarias y arrendatarias de tierras. Los líderes nacionalistas buscaron conscientamente la colaboración de estos campesinos, y también de la incipiente clase obrera de las ciudades, convencidos de que para que triunfase una rebelión contra las autoridades españolas era necesario contar con la colaboración de las masas, y no sólo con la actuación de unas élites $\sin$ apoyos y $\sin$ bases $^{18}$.

Otro sector fundamental en la formación de una identidad filipina y en la lucha por la igualdad de derechos, lo constituyeron el clero nativo y los movimientos religiosos autóctonos de las islas. El clero nativo se encontraba en conflicto con la administración colonial porque ésta había intentado, desde las primeras décadas del siglo XIX, contrarrestar la influencia que pudieran tener entre la población, limitando cada vez más la acción parroquial que podían desarrollar. Un punto álgido en este enfrentamiento fue 1872, cuando, después del Motín de Cavite, fueron ejecutados tres sacerdotes

16 Maria Teresa Colayco, A Tradition of Leadership. Bank of the Philippine Islands, Manila, 1884. Precedentes de esta institución habían sido las casas de préstamo de filipinos prósperos, como Dámaso Gorricho, Francisco Rodríguez, fundador del Rodríguez Bank, o Mariano Tuason, todas ellas iniciativas locales para proporcinar préstamos a proyectos de desarrollo filipino. Antonio REgIDOR y Warren MASON, Commercial Progress in the Philippines, London, 1905.

17 John A. Larkin, [15], p. 98. Maximo Kalaw, The Development of Philippine Politics, 1872 to 1920, Manila, 1926. Renato Constantino, The Making of a Filipino: A Story of Philippine Colonial Politics, Quezon City, 1969.

18 JN. SCHUMACHER, The Propaganda Movement, 1880-1895, Manila, 1973. 
filipinos muy queridos y populares, acusándoles de estar detrás de aquella rebelión. Esos hechos y la injusticia de su situación dentro de la Iglesia católica, propiciaron la propagación de un sentimiento nacionalista muy fuerte entre el clero nativo filipino, que le llevó a apoyar la rebelión contra España en $1896^{19}$.

Los movimientos religiosos milenaristas defensores de la "pasyon" (nombre que se derivaba de la pasión de Cristo), fueron un grupo menos organizado políticamente, pero que tuvo fuerza en su oposición a la administración española, y sobre todo a las órdenes españolas. La "pasyon" era una práctica religiosa mixta entre un catolicismo muy populista y creencias paganas y animistas profundamente arraigadas. Las ideas y las manifestaciones religiosas de este grupo no se ajustaban a las enseñanzas de los religiosos españoles. El movimiento tenía un carácter fácilmente subversivo porque prometía, a través de la redención y la resurrección, el cielo en la tierra, e impulsaba a la acción inmediata. La "pasyon" proporcionó imágenes y sentimientos colectivos, que fueron utilizados por los líderes de la rebelión anticolonial para aglutinar a las masas ${ }^{20}$.

Todos estos grupos, hacendados filipinos, élites económicas, clases ilustradas, campesinos y obreros asalariados, clero nativo, movimientos religiosos, se unieron contra la administración española, descontentos por la desigualdad legal, por la ausencia de derechos fundamentales, aglutinados contra un enemigo común en defensa de unos intereses, diferentes unos de otros, pero coincidentes todos en ser cada vez más divergentes de los de los españoles. En esa situación, ¿por que no rebelarse unidos contra el poder colonial, en una lucha común por la independencia que les permitiera el desarrollo de una nación libre en la cual cada grupo pudiera llevar a cabo sus intereses? Sin embargo, pese a la coincidencia de intenciones, la lucha nacionalista que fue forjando la nación filipina no fue un movimiento uniforme. El objetivo común era la lucha por sus derechos y la independencia de España. Pero existieron intereses distintos y división de opiniones en el seno del movimiento, por lo que a menu-

19 JN. SCHUMACHER, Revolutionary Clergy and the Nationalist Movement, 1850-1903, Quezon City, 1976 y Readings in Philippine Church History, Quezon City, 1987. City, 1979.

20 R. ILETO, Pasyon and Revolution: Popular Movements in the Philippines, Quezon R. I., $1998, \mathrm{n}^{\circ} 213$ 
do las distintas fracciones eligieron vías de expresión y medios diferentes para manifestar su descontento contra España ${ }^{21}$.

En el origen del movimiento independentista filipino se pueden diferenciar distintos motivos de conflicto. En primer lugar, la reclamación de igualdad, libertades y derechos políticos protagonizada por los ilustrados filipinos, que se sumaba al descontento popular ante los abusos cometidos por los representantes de la administración española. En segundo lugar, el descontento por la destacada posición que ocupaban las órdenes religiosas españolas en muy variados sectores de la vida de las islas; descontento que se veía, además, agravado por la situación de trato desigual y de diferencia de oportunidades, derechos y funciones entre el clero español y el nativo. La resistencia contra la labor misional de las órdenes era importante también porque en Filipinas existía una profunda diversidad religiosa, con cultos muy arraigados entre la población, como podían ser las creencias animistas, la religión musulmana o formas sincréticas de cristianismo milenarista. En tercer lugar, la disconformidad con el sistema de propiedad de la tierra, controlada en gran medida por las órdenes religiosas, lo cual dificultaba el despegue económico, - agrario e industrial—, de una nueva clase filipina cada día más implicada en la transformación económica de su nación.

Las manifestaciones del descontento filipino contra el gobierno español y contra la labor de las órdenes religiosas en el archipiélago pueden encontrarse de forma ya constante desde principios del siglo XIX. En 1823 hubo una primera revuelta en el ejército, al protestar un grupo de oficiales por las discriminaciones de los filipinos, que no podían ascender del mismo modo ni hasta las categorías que alcanzaban los españoles. En 1832 un movimiento religioso alentado por Apolinario de la Cruz fue primero prohibido y luego duramente sancionado. En 1843 estalló un motín de oficiales, en el que ya se luchó en favor de la independencia, aunque el movimiento no tuvo éxito y fue reprimido por soldados filipinos leales al Gobierno español. En los años sesenta se difundieron varios panfletos redactados por clérigos filipinos, como el padre Pedro Peláez o el padre José

21 JN. SChumacher, "Recent Perspectives on the Revolution", Philippine Studies; MC. Guerrero, "Understanding Philippine Revolutionary Mentality, Philippine Studies,; R. ILETO, "Critical Issues in 'Understanding Philippine Revolutionary Mentality", Philippine Studies. Usha MAHAJANI, Philippine Nationalism. External Challenge and Filipino Response, 1565-1946, St. Lucía, 1971. Gregorio ZAIDE, The Philippine Revolution, Manila, 1954. 
Apolonio Burgos, en los que defendían sus derechos frente a la discriminación y protestaban contra la negativa consideración que las autoridades españolas les atribuían a fin de mantenerles alejados del poder y disminuir su influencia sobre la población. En 1872 tuvo lugar la principal manifestación contra el Gobierno español, el Motín de Cavite.

Junto a estos movimientos de descontento que empezaban a proliferar en Filipinas, fue surgiendo una nueva élite ilustrada, universitaria, educada en Europa e impregnada de ideales políticos acordes con los tiempos, que reclamaba la igualdad de derechos y oportunidades para todos los filipinos y la modernización de la sociedad, denunciaba las injusticias y arbitrariedades de la administración colonial, aunque todavía no llamaba a la rebelión contra España. A partir de 1870 esa élite ilustrada se organizó a través del Movimiento de Propaganda para luchar en favor de la igualdad legal, la reforma institucional y la modernización económica. Este movimiento presentó sus primeras demandas todavía dentro del marco colonial, sin cuestionar la relación con España. Pero cuando comprendieron que el Estado español no atendería sus reclamaciones y no les reconocería como iguales, modificaron sus objetivos y, a partir de 1890 , comenzaron a luchar por el autogobierno y la independencia ${ }^{22}$.

Las ideas de este grupo quedaron representadas por el primer líder del movimiento independentista filipino, José Rizal. Nacido en el seno de una familia acomodada e ilustrada, su padre explotaba una plantación de azúcar y su madre era una mujer culta y graduada. Estudió medicina en la Universidad de Santo Tomás. Amplió sus estudios en España, donde dirigió una organización de filipinos que publicaba su propio periódico, La Solidaridad, y también estudió en Francia y en Alemania. Entre sus obras están A la juventud filipina (1879), El consejo de los dioses (1880), la más destacada, Noli me tangere (1887) y El filibusterismo (1891). En ellas abogaba por la reforma del gobierno y de las costumbres perniciosas de españoles y filipinos, por la creación de una sociedad libre y justa en la cual cada grupo pudieran desarrollar en armonía sus mejores capacidades, y por potenciar la modernización del país. Defendía la representación en Cortes y demandaba la garantía de todas las libertades democráti-

22 Usha MAHAJAni, [21]. Gregorio ZAIDE, [21] y Philippine Political and Cultural History, Manila, 1957.

R. I., $1998, \mathrm{n}^{\circ} 213$ 
cas; solicitaba que los filipinos pudieran ocupar puestos en su propio gobierno y que, aunque las órdenes religiosas permanecieran en Filipinas, no ejercieran tareas políticas. Es decir, era, en origen, un reformista convencido, pero las soluciones que proponía no cuestionaban la unión con España ${ }^{23}$.

$\mathrm{Su}$ posterior radicalización política tuvo mucho que ver con cuestiones personales. En 1890 fueron requisadas a su familia las tierras que explotaba en Calamba, con la excusa de que no pagaba las rentas necesarias a los propietarios dominicos. Rizal recurrió esta sentencia ante el Tribunal Supremo, pero cuando su causa fue rechazada, comprendió que los derechos de los filipinos nunca se reconocerían frente a los de los españoles. Decidió regresar a su país para concienciar a su pueblo de que era necesario luchar por las reformas. No se podía continuar esperando a que el Gobierno español hiciera las concesiones deseadas, que nunca llegarían. Era necesario preparar al pueblo filipino para el autogobierno. Ese camino, preconizaba todavía, debía hacerse de manera pacífica, evitando cualquier acción violenta. Con ese objetivo, en Junio de 1892, Rizal regresó a Manila y fundó la Liga Filipina. Sin embargo, el Gobernador General, temeroso de la influencia que pudiera tener entre sus conciudadanos, le arrestó por un motivo futil y le exilió a Dapitán. Aunque sus seguidores trataron de proseguir la defensa de sus ideales siempre por métodos pacíficos, dirigidos por Domingo Franco, un industrial de Visayas, pronto hubo otro sector que se hizo con el liderazgo de la lucha por la independencia.

Era el Katipunan, formado por Andrés Bonifacio. Sus ideas eran más radicales y reivindicaban el uso de la violencia para lograr los cambios deseados. Tenían el apoyo de la pequeña burguesía y de la población urbana y rural menos favorecida. El movimiento se fue extendiendo gracias a una gran labor de propaganda a través del períodico Kalaayan, en el que se llamaba ya a los filipinos a la lucha armada contra los españoles. Paulatinamente fueron organizando una lucha de guerrillas, con gran éxito popular. Finalmente, el 26 de Agosto de 1896, Bonifacio, en una reunión conocida como "el Grito de Balintawak", en un gesto simbólico contra las autoridades coloniales, rompió su cédula personal, y ratifica la decisión de levantarse en armas contra el Gobierno español. Cuatro días más tarde la rebe-

23 TA. Agoncillo, Rizal and the Philippine Revolution, Manila, 1961. 
lión se había estallado en las islas. Comenzó en Manila y se extendió rapidamente por sus alrededores ${ }^{24}$.

El Gobernador Ramón Blanco telegrafió a España pidiendo refuerzos y el 30 de Agosto declaró el estado de emergencia en ocho provincias. Estableció un período de gracia de cuarenta y ocho horas, declarando que si en ese tiempo los insurrectos se rendían, no sufrirían represalias. Su propuesta no tuvo éxito, y la insurrección se extendió por toda la isla. En el enfrentamiento entre españoles y filipinos fueron arrestadas muchos ilustrados que se habían destacado en la lucha por el desarrollo y la independencia de su nación, y entre ellos José Rizal, que fue fusilado el 30 de Diciembre de 1896. Fue un tremendo error humano y político. Rizal era el símbolo de la lucha por la independencia y como tal fue castigado, a pesar de no tener nada que ver con los últimos acontecimientos acaecidos en Filipinas. Cuando estalló la insurreción estaba en un barco rumbo a Cuba, donde iba a trabajar como médico, pero al llegar a Barcelona fue apresado y reenviado a Manila, donde se celebró un juicio sumarísimo en el cual fue condenado a muerte. Sin embargo, Rizal nunca apoyó el enfrentamiento armado contra España. Con su muerte se convirtió en el héroe de la revolución.

Durante los meses siguientes, al hilo de las batallas, se originó un problema de liderazgo en el movimiento independentista, entre dirigentes que encarnaban distintos grupos sociales. Bonifacio, que no era un militar ni gran estratega, comenzó a perder posiciones. Frente a él emergió la figura de Emilio Aguinaldo, un terrateniente mestizo, oficial del ejército, y victorioso en sus maniobras en torno a Cavite. En Octubre de 1896, Aguinaldo redactó sendos manifiestos al pueblo filipino, a través de los cuales trataba de organizar la lucha revolucionaria contra los españoles. En medio de la refriega, y con profundas disensiones en el movimiento insurrecionista, en Marzo de 1897, se creó un gobierno revolucionario, para el cual Aguinaldo fue elegido presidente, mientras que Bonifacio era nombrado ministro de interior. Sin embargo, las luchas intestinas entre los partidarios de cada uno de los líderes, defensores de proyectos políticos diferentes, provocaron conjuras y reuniones que acabaron en un juicio contra Bonifacio, en el cual éste fue considerado culpable de

${ }_{24}$ TA. Agoncillo, The Revolt of the Masses: The Story of Bonifacio and the Katipunan, Quezon City, 1956.

R. I., $1998, \mathrm{n}^{\circ} 213$ 
traición y condenado a muerte. Aguinaldo revocó la pena, pero en una maniobra todavía hoy poco clara, un pistolero asesinó al fundador del Katipunan el 10 de Mayo de 1897. Aguinaldo quedaba como líder indiscutible del movimiento independentista filipino.

Desde principios de 1897 un nuevo Gobernador General, Camilo Polavieja, había intensificado la lucha contra los revolucionarios. En Mayo, Manila y Cavite habían vuelto a manos españolas. Aguinaldo tuvo que refugiarse en Biac-Na-Bató. Allí reagrupó sus fuerzas, y, en Noviembre de 1897, promulgó la primera constitución filipina, que defendía una carta de derechos fundamentales, la separación de España y la declaración de Filipinas como república independiente.

Dado que la lucha armada continuaba sin solución inmediata, se nombró a otro Gobernador General, Fernando Primo de Rivera, que intentó un nuevo método para acabar con las hostilidades. Invitó a Aguinaldo a negociar una paz justa. Las negociaciones fueron largas y hubo al menos dos pactos preliminares. Finalmente, el 14 de Diciembre de 1897, se llegó a un acuerdo definitivo, el Pacto de BiacNa-Bató. En él se establecía que España pagaría 800.000 pesos a los rebeldes a cambio de que entregasen las armas y reconocieran la soberanía de España. Se introducirían reformas - no especificadas- una vez que la paz se hubiera restablecido. Aguinaldo y otros veintisiete líderes revolucionarios serían conducidos a Hong-Kong. Este acuerdo acabó con la revolución, aunque sus cláusulas no fueron totalmente cumplidas por ninguna de las dos partes, y ni la suma de dinero se distribuyó de la manera pactada, ni las reformas fueron las esperadas. Tampoco se entregaron todas las armas ni la lucha cesó de manera absoluta. Pero el Gobierno español pudo decir que empezaba 1898 con las islas prácticamente pacificadas y un renovado interés por su futuro, que se reflejaría en nuevos propósitos políticos y en una fuerte incentivación de la economía filipina.

Sin embargo, la paz no se restableció totalmente y la lucha por la independencia continuó. No todos los rebeldes aceptaron las cláusulas del tratado de Biac-Na-Bató, por lo que continuó habiendo luchas esporádicas. Esos focos revolucionarios se incrementaron durante la guerra hispano-norteamericana, y prosiguieron luego, cuando, al ver que no llegaba la ansiada independencia, comenzó la lucha entre filipinos y norteamericanos en Febrero de 1899. Un año después, en Abril de 1901, Emilio Aguinaldo rindió sus tropas. Pese a ello todavía continuó habiendo puntos de resistencia. El último de 
los rebeldes, Miguel Malvar, se rindió finalmente en Batangas en 1907, acabando así el proceso revolucionario por la independencia.

\section{FILIPINAS, ENCRUCIJADA INTERNACIONAL}

La islas Filipinas despertaron interés en el mundo internacional de 1898 , primero, en tanto que territorio colonial donde las potencias tenían desde hace años arraigados intereses económicos y estratégicos. Segundo, como espacio cuyo futuro se puso en cuestión durante la guerra hispano-norteamericana. Mientras que, a raíz de la contienda, el porvenir de Cuba o de Puerto Rico no fue discutido a nivel internacional, se aceptó la aplicación de la Doctrina Monroe en aquellas islas del Caribe y las potencias no se plantearon intervenir en ellas, por contra, el destino de Filipinas y de las islas españolas de la Micronesia despertó un vivo debate internacional y provocó la acción de distintos países, que enviaron barcos a Manila y entablaron negociaciones diplomáticas en torno a la cuestión. Todas las grandes potencias - gobiernos, grupos de presión, opinión pública- se interesaron por lo que ocurría en Filipinas y la mayoría de ellas participó en la discusión sobre su futuro. ¿Por qué este interés de las potencias? ¿Qué relación las unía con Filipinas?

En los años finales del XIX tenían consulados en Manila las siguientes naciones: Austria-Hungría, Brasil, Chile, Dinamarca, Ecuador, Francia, Alemania, Gran Bretaña, Hawai, Italia, Japón, Liberia, Méjico, Holanda, Portugal, Rusia, Suecia, Noruega, Suiza y Estados Unidos. El censo de población de 1983 reflejaba como residentes en Manila: 160.896 filipinos; 15.157 chinos mestizos; 15.157 chinos; 4.189 españoles; 3.849 españoles mestizos; 250 residentes extranjeros. La cifra de residentes extranjeros es bastante baja, pero hay que tener en cuenta que está referida sólo a Manila y que una buena parte de las compañías que operaban en las Filipinas estaban radicadas fuera de esta ciudad ${ }^{25}$. De esa población, los residentes europeos $\mathrm{y}$ americanos se dedicaban fundamentalmente al comercio o a la

\footnotetext{
25 Las cifras no siempre coinciden. Según los informes consulares británicos (Consular Report $n^{\circ}$ 203, Agosto de 1897), había 25.000 residentes europeos en las islas, de un total de población de 8 millones de habitantes. De ellos, unos 12.000 estaban establecidos en Manila, pero no se especifican diferencias de nacionalidad o procedencia.
} 
banca, trabajaban en compañías exportadoras y de comunicaciones, o eran inversores, abogados, procuradores, ingenieros y médicos.

Respecto a los rasgos generales que caracterizaron el comercio de Filipinas a fines de siglo, puede señalarse que el volumen de comercio en las islas fluctuó en el último tercio del siglo XIX entre 30.000 y 40.000 pesos anuales, entre exportaciones e importaciones. Algo más de la mitad de esa cantidad eran exportaciones de las islas y menos de esa cifra, importaciones. Gran Bretaña, China y los puertos británicos en Asia, España y Estados Unidos eran, por ese orden, los principales beneficiarios del comercio con Filipinas.

Como se puede comprobar en el cuadro 1, en 1881 Gran Bretaña controlaba el $34 \%$ del total del comercio de las islas. Otro $34 \%$ correspondía al comercio de Filipinas con China, Hong-Kong, Singapur y otras posesiones británicas en Asia. España controlaba en torno al $6 \%$ del total de las importaciones y exportaciones. A Estados Unidos le correspondía un $22 \%$ del comercio total. A partir de 1881, y debido a las medidas adoptadas por España en beneficio del comer-

\section{CUADRO 1}

COMERCIO DE FILIPINAS CON OTRAS POTENCIAS EN 1881 Y 1893 (PORCENTAJES)

\begin{tabular}{|l|r|r|r|r|r|r|}
\cline { 2 - 7 } \multicolumn{1}{c|}{} & \multicolumn{2}{c|}{ \% IMPORTACIONES } & \multicolumn{2}{c|}{ \% EXPORTACIONES } & \multicolumn{2}{c|}{$\%$ TOTAL } \\
\cline { 2 - 7 } \multicolumn{1}{c|}{} & 1881 & 1893 & 1881 & 1893 & 1881 & 1898 \\
\hline GRAN BRETAÑA & 28.6 & 26.7 & 38.0 & 44.9 & 33.7 & 37.3 \\
POS. GB EN ASIA & 53.8 & 0.9 & 18.5 & 2.3 & 34.7 & 1.7 \\
ESTADOS UNIDOS & 4.1 & 6.0 & 37.5 & 13.5 & 22.2 & 10.3 \\
ESPAÑA & 7.3 & 32.1 & 4.4 & 8.6 & 5.8 & 18.4 \\
CHINA & 2.7 & 14.0 & 0.2 & 21.9 & 1.3 & 18.6 \\
ALEMANIA & 2.6 & 7.4 & - & 0.9 & 1.2 & 3.3 \\
FRANCIA & - & 3.0 & - & 1.0 & - & 1.8 \\
INDOCHINA FR. & - & 3.2 & - & 0.3 & - & 1.3 \\
\hline
\end{tabular}

* En 1893 China incluye Hong-Kong, y las posesiones británicas en Asia se refieren sólo a Singapur. En 1881 no hay datos para Francia. Las cantidades están expresadas en pesos USA. El ratio era de dos pesos españoles por un dólar americano.

Fuente: Report of the Philippine Commission ${ }^{26}$.

26 Report of the Philippine Commission, vol. IV, Washington, Government Printing Office, Paper $n^{\circ}$ XVI, Commerce, p. 61. 
cio con la Península (medidas industriales, financieras y de tarifas), el comercio con España aumentó notablemente, especialmente porque se incrementaron las exportaciones de productos peninsulares hacia Filipinas. De esta forma se pasó a que Gran Bretaña controlara un $37 \%$ del comercio total (el porcentaje aumentaba gracias a las importaciones de productos filipinos a Gran Bretaña, porque sin embargo disminuyó la entrada de productos británicos en Filipinas), China y los puertos asiáticos un $20 \%$, España un $18.4 \%$ (en este caso, el crecimiento en el porcentaje total se explica por las exportaciones peninsulares a Filipinas, ya que las importaciones de productos filipinos a España continuaban siendo muy bajas, lo cual aumentaba el abismo entre las dos naciones), y Estados Unidos un $10 \%$ del total del comercio.

\section{CUADRO 2}

COMERCIO POR PAÍSES DE ORIGEN Y DESTINO, 1896

\begin{tabular}{|c|c|c|}
\hline PAÍSES & IMPORT. DESDE FIL. & EXPORT. A FIL. \\
\hline GRAN BRETAÑA & $\$ 6,223,426$ & $\$ 2,063,798$ \\
\hline FRANCIA & \$ $1,990,297$ & $\$ 359,796$ \\
\hline ALEMANIA & $\$ 223,720$ & 774,928 \\
\hline BÉLGICA & $\$ 272,240$ & $\$ \quad 45,660$ \\
\hline ESPAÑA & $\$ 4,434,261$ & $\$ 7,972,637$ \\
\hline JAPÓN & $\$ 1,332,300$ & $\$ \quad 92,823$ \\
\hline CHINA & $\$ \quad 56,137$ & 97,717 \\
\hline ESTADOS UNIDOS & $\$ 4,383,740$ & 94,597 \\
\hline CANADÁ & $\$ 1,242,441$ & - \\
\hline
\end{tabular}

Fuente: Commercial Relations 27.

27 Commercial Relations of the United States with Foreign Countries during the year 1898. Issued from the Bureau of Foreign Commerce, Department of State, Washington, Government Printing Office, 1899, vol I, pp. 140-141.

The average value of the trade of the Philippine is greater than indicated in the above table, having suffered in the past few years on account of political conditions. Great Britain imported from the Philippines in 1893 to the value $\$ 10,607,000$, and exported nearly $\$$ $1,500,000$ more than the shipments in 1897. France imports three times as much as she did in 1893 , but her exports have disminished in an even larger proportion, from over $\$ 2,000,000$ to $\$ 350,000$. China imports more than twice as much, but exports considerably less than in 1893 ; and United States commerce, which was $\$ 9,314,235$ in 1893 , fell to $\$ 4,478,337$ in 1897 . Our trade in 1893 was: imports from Philippines, $\$ 4,099,525$, exports to Philippines, $\$ 147,846$.

R. I., 1998, n. $^{\circ} 213$ 
En un análisis comparado de la implicación de las potencias en Filipinas vemos que, a fines del XIX, Gran Bretaña era, después de España, el país que tenía mayores intereses en las islas. Dominaba el

\section{CUADRO 3}

PRINCIPALES ARTÍCULOS DE IMPORTACIÓN Y EXPORTACIÓN, 1896

IMPORTACIONES DE FILIPINAS

\begin{tabular}{|l|r|r|c|c|}
\hline PAísES & \multicolumn{1}{|c|}{ ABACA } & TABACO & COPRA & \multicolumn{1}{c|}{ AZUCAR } \\
\hline GRAN BRETAÑA & $\$ 3,694,214$ & $\$ 716,767$ & $\$ 222,404$ & $\$ 1,512,703$ \\
FRANCIA & 76,754 & 86,451 & $1,787,198$ & - \\
ALEMANIA & 166,600 & 31,654 & - & - \\
JAPÓN & 100,993 & 64,477 & - & $1,156,411$ \\
ESPAÑA & - & $2,533,150$ & - & 413,794 \\
ESTADOS UNIDOS & $2,701,651$ & - & - & $1,199,202$ \\
\hline
\end{tabular}

EXPORTACIONES A FILIPINAS

\begin{tabular}{|l|c|c|c|r|}
\hline PAÍSES & $\begin{array}{c}\text { MANUFACTURAS } \\
\text { ALGODÓN }\end{array}$ & $\begin{array}{c}\text { MANUFACTURAS } \\
\text { DE SEDA }\end{array}$ & $\begin{array}{c}\text { MANUFACTURAS } \\
\text { DE LANA }\end{array}$ & ROPA \\
\hline G. BRETAÑA & $\$ 1,268,087$ & $\$ 12,205$ & $\$ 17,943$ & $\$ 6,273$ \\
FRANCIA & 143,223 & 81,720 & 2,493 & 3,912 \\
ALEMANIA & 111,028 & 43,792 & 4,286 & 99,426 \\
JAPÓN & 120 & 4,418 & - & 157 \\
USA & 2,164 & - & - & - \\
\hline
\end{tabular}

\begin{tabular}{|l|c|c|c|c|}
\hline PAíSES & MAQUINARIA & METALES & CARBÓN & PROVISIONES \\
\hline G. BRETAÑA & $\$ 151,630$ & $\$ 185,413$ & $\$ 16,856$ & $\$ 79,455$ \\
FRANCIA & 10,353 & 5,035 & - & - \\
ALEMANIA & 29,036 & 146,370 & - & 31,654 \\
JAPÓN & 250 & 398 & 40,996 & 7,429 \\
\hline
\end{tabular}

Fuente: Commercial Relations of the United States with Foreign Countries during the year $1898^{28}$.

28 Commercial Relations of the United States with Foreign Countries during the year 1898. Issued from the Bureau of Foreign Commerce, Department of State, Washington, Government Printing Office, 1899, vol I, pp. 140-141.

R. I., $1998, \mathrm{n}^{\circ} 213$ 
tráfico comercial, tanto de exportación como de importación ${ }^{29}$. Ocupaba un papel fundamental en las comunicaciones, puesto que ingenieros ingleses habían construido el único ferrocarril que existía en Luzón (de Manila a Dagupan), habían trazado diversas carreteras y el cable que unía Manila con Hong-Kong era de propiedad británica. En Septiembre de 1897 se decidió conceder a una compañía británica el tendido de un nuevo cable de telégrafo entre Manila y las islas de Panay y Cebú ${ }^{30}$. Además, estaban establecidos en las islas varios bancos y compañías comerciales, entre las cuales destacaban The Hong-Kong \& Shangai Banking Corporation, The Chartered Bank of India, Australia and China, The Manila Railway Coy.Ltd., Smith-Bell Co., Macleod \& Co., WS Stevenson Co., Gold Mining $C^{o}$ of Paracole \& Mambulao $^{31}$. Finalmente, dada la posición que Inglaterra ocupaba en Extremo Oriente, el Gobierno británico también tenía un interés estratégico por aquellos archipiélagos.

\section{CUADRO 4}

\section{PRINCIPALES PRODUCTOS EXPORTADOS DE ESPAÑA A FILIPINAS EN 1895}

\begin{tabular}{|c|c|c|}
\hline & ros & \\
\hline latados y & kilos & $\ldots \ldots \ldots \ldots \ldots \ldots \ldots$ \\
\hline (1) & & 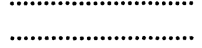 \\
\hline (1) & “ & 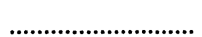 \\
\hline (1) & "6 & $x_{1}$ \\
\hline 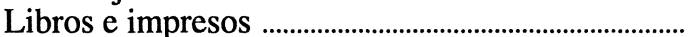 & "6 & $p_{1}$ \\
\hline$\ldots$ & “ & 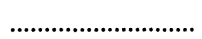 \\
\hline ........... & “ & 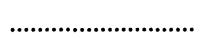 \\
\hline & "6 & ............................. \\
\hline & litros & \\
\hline
\end{tabular}

Fuente: Report of the Philippine Commision,Paper ${ }^{\circ} \mathrm{XVI}, \mathrm{p} .71$

29 En torno al $80 \%$ de las exportaciones del archipiélago y el $70 \%$ de las importaciones a Filipinas se hacían en barcos ingleses. Public Record Office, FO 72-2084, Memorial from British merchants engaged in trade with the Philippines, June 1898.

30 Public Record Office, FO 72, 2045, 30 September 1897, commercial n ${ }^{\circ}$ 5. "A concession has been granted by the Spanish Government to the Eastern Telegraph Company to extend their cable from Manila to the adjacent islands of Panay and Cebu in the Philippine Archipelago".

31 Otras compañías y comerciantes británicos establecidos en Filipinas eran: Holliday Wise Co., Kerr Co., Forbes Mem Co., HJ Andrews Co., Warner Baines Co., RV. Dimcan Co., Johnston Goe Booth Co., Watson Co., Suidlay Co., Glenlochy, E. Wookey, Wilson, John Mackay, Chas H Gundall, J Auckterlon, Boyle \& Earnsham, HS Dean, Public Record Office, FO72, 2045, 13 Agosto 1897. 
En los años objeto de estudio, Gran Bretaña ocupó siempre el primer lugar como país importador y exportador a Filipinas. En las últimas décadas del siglo XIX el comercio entre Gran Bretaña y Filipinas suponía un $35 \%$ del total del comercio de las islas, cantidad que aumentaba hasta representar un $70 \%$ si se le sumaba el comercio con Hong-Kong, Singapur y otras posesiones británicas en Asia. Las importaciones de productos filipinos a Gran Bretaña siempre fueron mayores que las exportaciones de bienes manufacturados británicos a las islas. Este desequilibrio aumentó con los años, al incrementarse la llegada a Filipinas de productos manufacturados de otros países, fundamentalmente de España, Alemania y Francia. Entre 1870 y 1898 las importaciones filipinas a Gran Bretaña continuaron aumentando de forma constante. Sin embargo, las exportaciones británicas disminuyeron, especialmente a partir de 1881 (adopción de una política proteccionista en las islas), con descensos significativos en 1892 (nuevo arancel español) y 1896 (revolución filipina) ${ }^{32}$. En 1898 el cónsul británico en Manila informaba que entre los productos que Gran Bretaña importaba de las Filipinas destacaban el azúcar, la copra y el ábaca, y en menor medida cacao e indigo ${ }^{33}$. Respecto a las exportaciones, Gran Bretaña enviaba a Filipinas textiles, fundamentalmente de algodón, y hierro de buena calidad, en barras y en láminas, para la construcción ${ }^{34}$.

El comercio de Alemania con las Filipinas aumentó notablemente en el último tercio del siglo XIX, coincidiendo con la expansión colonial iniciada en esas décadas, de forma tímida pero constante en tiempo de Bismarck, y consolidada con la adopción de la Weltpolitik promovida por Guillermo II. En 1881 las importaciones a Alemania de productos filipinos supusieron $485.000 \$$, mientras que las exportaciones alemanas fueron prácticamente nulas. En 1893 las importaciones de Filipinas fueron de 1.246.000 \$, y las exportaciones de $19.728 \$$, muy bajas también (sexto país exportador a Filipinas, $1,89 \%$ del total), pero alcistas respecto a la década anterior, a pesar de la desfavorable legislación aduanera española, lo cual re-

\footnotetext{
32 Report of the Philippine Commission, vol. IV, Washington, Government Printing Office, Paper $\mathrm{n}^{\circ}$ XVI, Commerce, pp. 65-66.

33 Public Record Office, FO 72, 2081, Consul at Manila, 1898, Consular \& Commercial, Report on trade in the Philippine Islands.

34 Consular Reports, No.1932, Report on Trade and Commerce of the Philipine Islands for the year 1896.
} 
fleja el aumento de los intereses alemanes en el Pacífico en general y en estas islas en particular ${ }^{35}$. Alemania importaba de Filipinas ábaca y tabaco; exportaba fundamentalmente metales o productos metálicos manufacturados, maquinaria y textiles ${ }^{36}$. El cónsul francés en Manila señalaba que en 1896 estaban establecidas en las islas quince compañías alemanas, dedicadas fundamentalmente al comercio y a potenciar las posibilidades de inversión en maquinaria, construcción o envíos de metales.

Sin embargo, el interés de Alemania por las Filipinas conviene no medirlo sólo en términos económicos, sino reconocer también su vinculación con el imperio colonial que el kaiser Guillermo II pretendía crear en el Pacífico. Alemania había entrado tarde en la carrera colonial, pero dado su crecimiento industrial y naval, y sobre todo, conocidos los planteamientos de engrandecimiento en política exterior y los deseos de participar en el reparto del mundo, las Filipinas podrían ser un punto de especial significación que se sumara a las posesiones coloniales que ya tenía en las islas Marshall, en Nueva Guinea o en Samoa, y que le diera nuevas bazas en sus ambiciones en China.

Francia tenía distintos intereses en Filipinas. En gran medida estaban relacionados con su colonia de Indochina, desde donde enviaba carbón y caucho. Además estaban asentadas en las Filipinas dos compañías francesas de cierta importancia, la Societé Eiffel (Levallors \& Perret), que había construido el puente de Manila y numerosos puentes metálicos en el interior de la isla de Luzón. Intentaba también obtener la concesión de una nueva vía férrea en el archipiélago. La segunda compañía era la Société de Tabacs, con dos tercios de capital francés y dos delegados, un español, M. Correa y un francés, M. Villement. Estaba instalada en las provincias de la Isabella y de Cagallan. Esta compañía, además de dedicarse al cultivo y exportación de tabaco, exportaba también ábaca, azucar, ron y licores. A fines del XIX había en las islas cincuenta o sesenta residentes franceses, en su mayoría comerciantes o delegados de las

35 Report of the Philippine Commission, vol. IV, Washington, Government Printing Office, Paper $\mathrm{n}^{\circ}$ XVI, Commerce, p. 67.

36 Commercial Relations, [28] pp. 140-141.

R. I., $1998, \mathrm{n}^{\circ} 213$ 
compañías comerciales, y el resto, religiosos católicos del convento de la Asunción en Manila ${ }^{37}$.

Respecto a la opinión que tenían de las Filipinas en esos últimos años de dominación española, las autoridades francesas, conocedoras de las islas, resaltaban la necesidad de buscar un régimen político más liberal. Denunciaban el autoritarismo del Gobierno colonial, la omnipotencia de las órdenes religiosas y los abusos del poder teocrático. Consideraban que la opresión era tan excesiva que sólo podría conducir a la insurrección. Les preocupaba también el escaso aprovechamiento de las posibilidades de las islas y su deficiente explotación. Ponían el ejemplo de las minas de carbón de Sebou, muy poco efectivas, por lo que era necesario comprar ese mineral en el extranjero, señalaban la baja calidad del azúcar recolectado o la falta de industrias para la transformación de los productos. Filipinas exportaba 250.000 kilos de azúcar por año, pero sin embargo no existía una fábrica moderna donde refinarla, sino únicamente rústicos molinos que obtenían un producto poco competitivo en los mercados internacionales ${ }^{38}$.

La preocupación francesa por Filipinas, además de asentarse sobre bases comerciales e inversoras concretas en este archipiélago, se enmarcaba en los esquemas generales de la política francesa en Extremo Oriente y provenía del interés por proteger la seguridad de las posesiones francesas en Indochina ${ }^{39}$.

Japón también tenía intereses en Filipinas. Llevaba varios años fomentando el comercio con estas islas, con las Marianas y con las Carolinas ${ }^{40}$. Había tratado de establecer en ellas colonias de explota-

37 Archive Diplomatique du Ministère des Affaires Étrangères, Paris, Correspondence Politique et Commerciale, Espagne, NS 32, Direction Consulats et des Affaires Commerciales, Mayo 1898.

38 Archive Diplomatique du Ministère des Affaires Étrangères, Paris, Espagne, NS 30.

39 El cónsul francés en Manila, J. Hormans, escribía al Ministro de Asuntos Exteriores el 25 Abril 1898: "En el terreno de las interrogaciones, me parece que las islas Filipinas adquirirán en la guerra una importancia capital, también para la política francesa en el Extremo Oriente y para su seguridad, dada la existencia de las posesiones francesas en Indochina". Archive Diplomatique du Ministère des Affaires Étrangères, Paris, Espagne, NS32.

40 Archivo del Ministerio de Asuntos Exteriores, (AMAE), leg.1633, Memoria del encargado de Negocios en Japón al ministro de Estado, 3 Diciembre 1887 y 12 Abril 1888. En Marianas y Carolinas estaban establecidas varias empresas japonesas dedicadas a la obtención y exportación de la copra, y al comercio con pescado seco. 
ción y poblamiento ${ }^{41}$. Acababa de inagurar una línea de comunicaciones directa entre Tokio y Manila ${ }^{42}$. Sin embargo, la presencia japonesa en Filipinas no fue incentivada por el Gobierno español, que trató de obstaculizar un establecimiento importante de empresas o residentes de ese país, temeroso de que una implicación mayor en las islas pudiera dar lugar a futuras reivindicaciones japonesas que pusieran en peligro la seguridad de la colonia. Quizás por ello, en 1895, el cónsul francés en Manila señalaba que los intereses japoneses en Filipinas eran escasos. Sólo había 15 residentes de esa nacionalidad en Manila y dos bazares japoneses. No obstante, la publicación de un periódico japonés en las islas sugiera la existencia de una colonia de cierta importancia, aunque fuera oficiosa y no asentada legalmente. Respecto a los productos intercambiados entre los dos países, Japón vendía a Filipinas seda, algodón, abanicos, fósforos, biombos, pinturas, jabón de tocador, paraguas, quitasoles, termómetros, cristal, cuero, papel, madera, objetos de laca, porcelana, loza y carbón. A su vez importaba de Filipinas ábaca y otras fibras vegetales como lino, cáñamo y yute. También tabaco, añil, hierro, plomo, frutas, café, tejidos y sacos para contener arroz ${ }^{43}$.

Quisiera hacer una breve mención a China, nación que tenía unos intereses tan arraigados y tan particulares en Filipinas, que tendrán que ser objeto de otro estudio pormenorizado. Baste señalar aquí que la población china en Manila era numerosa, en torno a 100.000 personas, y que en sus manos estaba el pequeño comercio, por lo que ocupaba un lugar importante en la vida económica de las islas. También el comercio con China tenía una relevancia notable, ocupando este país uno de los primeros lugares en importaciones y exportaciones. No obstante, hay que indicar que a veces las cifras son engañosas, porque bajo ese epígrafe se incluía también el comercio con los puertos británicos en Asia, incluído Hong-Kong, con lo cual se dis-

${ }^{41}$ Las autoridades españolas estudiaron detenidamente esta cuestión. Aunque reconocían las ventajas que reportaría una emigración de familias campesinas a Filipinas, se decidió frenar cualquier proyecto en tal sentido, ante la amenaza que podría suponer para el gobierno de la colonia. AMAE, Política, 2537, subsecretario del Ministerio de Estado a ministro plenipotenciario en Tokio, 14 Noviembre 1891.

42 Compañía Nippon Isue Kaisha. Sobre este asunto, consultar $\mathrm{M}^{\mathrm{a}}$ Dolores ElIZALDE: “Japón y el sistema colonial de España en el Pacífico", Revista Española del Pacífico, n 5 , 1995, pp. 43-77.

${ }^{43} A M A E$, leg. 1634, Memoria sobre el comercio con Japón, 20 Marzo 1896; Informe sobre el comercio en el año 1897, 3 Enero 1898.

R. I., $1998, \mathrm{n}^{\circ} 213$ 
torsionaba el origen o destino de las mercancías que pasaban a través de los puertos chinos.

Un país tan pequeño y alejado de Filipinas como Bélgica, también tuvo su importancia en las islas. En 1864 una casa de Amberes, la compañía Man y Cia, trató de hacerse con el comercio del tabaco filipino puesto a disposición internacional por la administración del estanco, pero la iniciativa no llegó a formalizarse al no alcanzarse un acuerdo sobre los derechos y obligaciones de ambas parte. Años más tarde se fraguó otro proyecto en relación con estas islas: entre 1869 y 1875 Leopoldo II trató de comprar Filipinas o al menos una parte del archipiélago. La empresa no llegó a buen puerto y los intereses belgas se desviaron hacia Africa central y el Congo ${ }^{44}$. Sin embargo, el comercio de este país con Filipinas siguió teniendo una cierta envergadura. La importación de hierro belga alcanzó una extensión considerable. Se usaba fundamentalmente para construir vías de ferrocarril, balcones, ventanas, rejas o cubiertos, es decir, para aquellos objetos en los que se podía emplear una calidad de hierro inferior ${ }^{45}$. En relación con el total de mercancía importada y exportada por Bélgica durante el período 1892-1896 puede decirse que las importaciones desde Filipinas supusieron 27,487 dólares anuales y que las exportaciones a Filipinas sumaron 108,543 dólares también anuales, lo cual, representa un total de 136,030 de dólares por año ${ }^{46}$.

\section{LOS INTERESES NORTEAMERICANOS EN FILIPINAS}

El interés norteamericano por Filipinas comenzó a través de barcos balleneros que operaban por el Pacífico, y que en su búsqueda de cetáceos recalaron en el archipiélago, y también a través de compañías que comerciaban con China e hicieron de Manila un punto de escala en sus rutas comerciales. Los primeros productos por los que

\footnotetext{
44 Leopold GreINDL: A la recherche d'un état indépendant: Leppold II el les Philippines (1869-1875), Bruselas, Academie royale des sciences sociales d'outre mer/Classes de sciences morales et politiques, 1962. Josep M. Fradera: "El estanco de tabaco y la reforma de la hacienda filipina, 1760-1860", p.41.

45 Public Record Office, FO 72, 2081, Consul at Manila, 1898, Consular \& Commercial, Report on trade in the Philippine Islands.

46 Report of the Philippine Commission, vol. IV, Washington, Government Printing Office, Paper $n^{\circ}$ XVI, Commerce, p. 62.
} 
se interesaron fueron mercancías exóticas como conchas de tortuga o perlas que añadían un pequeño superplus a su tráfico habitual. Posteriormente, aquellos comerciantes se dieron cuenta de que el mejor partido que podían sacar de sus relaciones con Filipinas era la exportación de productos agrícolas que demandaba el mercado mundial. Empezaron entonces a exportar azúcar, ábaca, copra y café. Paulatinamente, según fue aumentando el tráfico de esos productos, decidieron establecer en las islas agentes permanentes. De esta forma, desde fines del siglo XVIII se asentaron comerciantes norteamericanos como Nathaniel Bowditch, William Peirce, Horatio Palmer, Ogden Edwards, o Richard Tucker.

Entre estos primeros comerciantes destacaron dos compañías. La Russell, Sturgis \& Co. que se instaló en 1828, tuvo su base en Binondo, y quebró en 1875. Y la Peele, Hubbell \& Co., creada por la asociación de George Hubbell, que comenzó a operar en Filipinas en 1822 , con otros socios, ya en 1856. La empresa se dedicó fundamentalmente al comercio del ábaca. Su sede central estuvo en San Gabriel, y tuvo gran importancia como dinamizadora de la economía de las islas, especialmente en las provincias de Albay y Camarines Sur. Muchos de los agentes que contrataba para la recolección del ábaca eran españoles peninsulares, que generalmente hacían de intermediarios con los productores filipinos, aunque también trabajó con británicos, chinos mestizos, tagalos o bikolanos. En 1881, la compañía facturó 4.5 millones de dólares en ábaca y azúcar, y controló más del $20 \%$ del total de las exportaciones de las islas. Sin embargo, en 1887, llegó a la bancarrota, al parecer como consecuencia de un fallido intento de expandir su actividad al mercado del azúcar ${ }^{47}$.

A través de la actividad de estas y otras compañías, los Estados Unidos consolidaron sus relaciones comerciales con las Filipinas hasta convertirse, en las dos décadas anteriores a la guerra hispanonorteamericana, en el ranking del total del comercio de las islas, en el tercer país en importancia, después de Gran Bretaña y de los establecimientos británicos en Asia. En 1881 controlaban el $22 \%$ del total del comercio en las islas. Estas cifras se debían sobre todo al alto consumo norteamericano de algunos de los principales produc-

\footnotetext{
47 Norman Owen, "Americans in the Abaca Trade: Peele, Hubbell \& Co., 18561875", en Peter Stanley, (ed.), Reappraising an Empire. New Perspectives on PhilippineAmerican History, Harvard, 1984, p. 203.
}

R. I., $1998, \mathrm{n}^{\circ} 213$ 
tos filipinos. Eran el segundo país en importaciones de Filipinas, después de Gran Bretaña, especialmente de ábaca y de copra. Sin embargo, las exportaciones de los Estados Unidos a Filipinas eran bastante más bajas, el cuarto país, después de Gran Bretaña, de China más los puertos británicos en Asia, y de España. El ratio entre importaciones y exportaciones era de 15 a $3^{48}$.

Respecto a los productos intercambiados entre ambos países en esos años finales de siglo, Filipinas exportaba a Estados Unidos ábaca, tabaco, copra, azúcar, arroz, café, bambú, cestas, coco, mangos, plátanos, piñas y algodón en rama; en menor medida oro, cobre, hierro y plomo. A su vez, importaba de Estados Unidos productos textiles manufacturados -en especial tejidos de algodón, seda y lana-, maquinaria, metales y productos metálicos ya manufacturados, carbón y provisiones varias ${ }^{49}$.

En 1898, el cónsul norteamericano en Manila, Oscar F. Williams, informaba que las exportaciones a Estados Unidos desde el distrito consular de Manila cobraban una creciente importancia. Se componían fundamentalmente de azúcar (el 55 por ciento de las exportaciones de este producto iba a Estados Unidos); ábaca (el volumen de las exportaciones de este producto a Norteamerica se habían incrementado hasta tal punto en el último año, que era un 544 por cien mayor que las exportaciones de esta fibra vegetal a todos los demás países juntos); copra, hojas de tabaco y cigarros también con un volumen importante; y en menor medida café, cuerdas, perlas, indigo, goma y cuero de búfalo. El total de las exportaciones de Filipinas a los Estados Unidos en la década 1887-1897 ascendía a 74.150.284 de dólares, lo cual representaba unos 7.415.028 de dólares por año, aunque de hecho no se repartieron de forma lineal, sino que fueron mayores en los primeros siete años y en 1895, 1896 y 1897 se redujeron a unos 4 millones y medio de dólares, aproximadamente; reducción que probablemente tendría relación tanto con el

\footnotetext{
48 Report of the Philippine Commission, vol. IV, Washington, Government Printing Office, Paper $n^{\circ}$ XVI, Commerce, p. 66; Bulletin No. 14 of the US Department of Agriculture, Section of Foreign Markets, 1898.

49 Commercial Relations of the United States with Foreign Countries during the year 1898. Washington, Government Printing Office, 1899, vol I, pp. 140-141.
} 
estado de insurreción que se vivía en las islas, como con las tarifas aduaneras adoptadas por Estados Unidos a partir de $1894^{50}$.

Cuando, durante la guerra hispano-norteamericana, se suscitó la posibilidad de que los Estados Unidos adquirieran una base naval en Filipinas, o incluso se anexionaran la totalidad del archipiélago, distintos sectores manifestaron su opinión. Los círculos económicos empezaron a subrayar las posibilidades que ofrecían estas islas a la economía norteamericana. En especial como consumidoras de bienes manufacturados o actividades industriales como las que podrían ofrecer los textiles, productos metalúrgicos, navieras y empresas constructoras de ferrocarriles. Y fundamentalmente, como base desde la que desarrollar el comercio norteamericano con China y con el Extremo Oriente.

Lo que determinó la política de Estados Unidos de reforzar su posición en el Pacífico, precisamente en esa fecha, fueron las actividades que las demás grandes potencias estaban desarrollando en ese ámbito. En 1898 pareció comenzar el reparto de China. Gran Bretaña, Francia, Alemania y Rusia aumentaron su influencia sobre áreas determinadas y ocuparon puertos estratégicos desde donde potenciar su penetración en aquél país. Esas acciones amenazaban las exportaciones americanas y en determinados círculos se comenzó a ver con preocupación como otras potencias les cerraban el paso de un mercado y de un campo de inversiones - el tendido de vías ferroviariasconsiderado de alto interés. En esas circunstancias la intervención en Filipinas, aprovechando el estado de guerra con España, podía proporcionar a Estados Unidos la posibilidad de salir de la posición secundaria que ocupaba en el Pacífico. Manila podía ser su Hong-Kong, su Kwangtung o su Kiaochow. Las voces para retener Filipinas comenzaron a extenderse nada más producirse la victoria de Dewey y fueron aumentando a lo largo del verano. Diferentes sectores apoyaban esta opción por motivos estratégicos, económicos y morales.

En primer lugar, los estrategas y oficiales de la Marina norteamericana, liderados por Alfred Mahan, que deseaban obtener una base naval desde la que defender los intereses americanos en Oriente. Los políticos expansionistas (Theodore Roosevelt, Henry Cabot Lodge), partidarios de la participación de Estados Unidos en la política mun-

50 Commercial Relations of The United States, Philippine Islands, 1898, pp.10951097; Bureau of Statistics, Treasury Department, 1898.

R. I., 1998, n. $^{\circ} 213$ 
dial, aprovecharon la ocasión para insistir en la misma dirección ${ }^{51}$. A las compañías que iniciaban el tendido de cables desde San Francisco a las costas asiáticas y cuyo objetivo era controlar las comunicaciones a través del Pacífico, también les interesaba adquirir una estación en las Filipinas ${ }^{52}$.

Además, los comerciantes norteamericanos que trabajaban para obtener beneficios en ese área desde hacía muchos años subrayaron el interés de las Filipinas. El propio cónsul en Manila, Oscar Williams, informó de que el volumen de las exportaciones filipinas a Estados Unidos era muy importante, especialmente en ábaca, azúcar, tabaco, copra, café, arroz y frutas, y que las importaciones de textiles, maquinaria y productos metálicos manufacturados aumentaban rápidamente. Junto al interés que las islas podían presentar por sí mismas, en la primavera y verano de 1898, numerosos círculos de negocios se interesaron por incrementar su participación en el comercio e inversiones en el Extremo Oriente - especialmente en China- y manifestaron al Presidente su apoyo a una política expansiva en este área. Las Filipinas podía ser una óptima base desde la que desarrollar sus proyectos orientales ${ }^{53}$.

51 Henry C. LoDGE, (ed.), Selections from the Correspondence of Theodore Roosevelt and Henry Cabot Lodge, 1884-1918, New York, 1925. Alfred T. MAHAN, The Influence of Sea Power Upon History, Boston, 1890. Julius W. PRATT, "The Large Policy of 1898", The Mississippi Valley Historical Review, vol. 19, 1932, pp. 219-242.

52 Senate Executive Documents, $\mathrm{n}^{\circ}$ 24, serial 4417, 57th Congress, First Session, Permission to the Pacific Cable Co. to land cable on Pacific.

53 El 25 de Marzo el Presidente recibió un telegrama de un asesor suyo desde Nueva York en el que se afirmaba que "las grandes coorporaciones de aquí creen ahora que vamos a tener guerra. Creáme que todas van a acogerla como un alivio después de tanto suspense", Papeles de William McKinley, W.C. Reick to J.R. Young, 25 Marzo de 1898, Biblioteca del Congreso, Washington. Lo mismo le hizo saber la National Association of Manufacturers, creada en 1895 e interesada en expandirse sobre nuevos mercados para reactivar la economía y superar la depresión de 1893. Otros ejemplos serían los del Commodore GW Melville: "Our Future in the Pacific. What we have there to hold and win", North American Review, CLXVI, 1898, pp. 281-296; Albert Shaw, "The Pacific Ocean is to be the theater of great events in the coming century. The next two generations of Americans will insist upon playing a large part in those events", Review of Reviews, XVII, 1898, p. 143; y en el mismo sentido le aconsejaron Frank Vanderlip, asistente del Tesoro; Frederic Emory, jefe de la Oficina para el Comercio Exterior; Irving M Scott, manager de la Union Iron Works; o Charles Cramp, lider de la industria naval norteamericana.

A través de sus palabras, se puede comprobar lo receptivo que fue McKinley a los argumentos de estos sectores :"Incidental to our tenure in the Philippines is the commercial opportunity to which American statesmanship can not be indifferent. It is just to use every legitimate means for the enlargement of American trade; but we seek no adventages in the 
Otro grupo importante que defendió la presencia americana en Filipinas fueron las asociaciones religiosas y los misioneros, que solicitaron la protección gubernamental para desarrollar su labor evangelizadora y educadora en aquellas islas. En general, los metodistas, baptistas, presbiterianos, congregacionistas, episcopalistas y otras confesiones minoritarias eran partidarias de desarrollar una nueva misión religiosa en Filipinas; los quáqueros y los unitarios se oponían a la guerra; los católicos miraban con cierto escepticismo el entusiasmo de los protestantes, señalando que los misioneros españoles ya habían evangelizado las islas, pero en su mayoría acabaron sumándose a los propósitos misioneros de las demás tendencias. La importancia que McKinley concedió a los argumentos religiosos se puede descifrar de sus palabras: "No había otra posibilidad para nosotros más que tomar las Filipinas, y educar, civilizar y cristianizar a los filipinos de la mejor forma que, por la gracia de Dios, que también murió por ellos, supiéramos hacerlo"54.

Hubo también otros círculos movidos por razones humanitarias, no teñidas de tintes religiosos. Esos sectores defendieron el deber contraído con los filipinos, al igual que con los cubanos, para li-

Orient which are not common to all. Asking only the open door for ourselves, we are ready to accord the open door to others. The commercial opportunity which is naturally and inevitably associated with this new opening depends less on large territorial possesion that upon an adequate commercial basis and upon broad and equal privileges". 55th Congress, 3d Session, House of Representatives, Instructions to the Peace Commissioners, Washington, 16 September 1898, Papers relating to the Foreign Relations of the United States, 1898, Washington, 1901, p. 907.

También pueden estudiarse las posiciones del mundo de los negocios a través de las obras de Julius W. PratT, "American Business and the Spanish-American War", The HispanicAmerican Historical Review, vol. 14, 1934, pp. 163-201. Walter LAFEBER, The New Empire: An Interpretation of American Expansion, 1860-1898, Ithaca, 1963. Wayne MORGAN, America's Road to Empire: The War with Spain and Overseas Expansion, New York, 1964. Thomas MCCORMICK, The China Market: America's Quest for Informal Empire, 18931901, Chicago, 1967. "The Philippines were insular stepping stones to the Chinese Pot of Gold", en Richard MiLler, American Imperialism in 1898. The Quest for National Fulfillment, Nueva York, 1970. Richard WELCH, Response to Imperialism. The United States and the Philippine-American War, 1899-1902, Chapel Hill, 1979. John DOBSON, Reticent Expansionism. The Foreign Policy of William McKinley, Pittsburgh, 1988. John OFFNER, An Unwanted War. The diplomacy of the United States and Spain over Cuba, 1895-1898, Chapel Hill, 1992. Walter LAFEBER, The American Age. U.S. Foreign Policy at Home and Abroad. 1750 to the Present, New York, 1994.

54 Julius W. PRATT, Expansionists of 1898: the Adquisition of Hawaii and the Spanish Islands, Baltimore, 1936 y A History of Unites States Foreign Policy, New York, 1955.

R. I., 1998, n. ${ }^{\circ} 213$ 
brarles del yugo español y enseñarles el camino hacia la libertad y la democracia que Estados Unidos encarnaba ${ }^{55}$.

La campaña anti-imperialista también tuvo gran resonancia. Estos círculos consideraron que la expansión colonial iba en contra de los principios y de las tradiciones más básicas en las que se apoyaban los Estados Unidos; entre ellos políticos como Carniage o Cleveland e intelectuales como Mark Twain. Hubo otros sectores que se opusieron a la anexión de las Filipinas por motivos menos altruistas, como los cultivadores de azúcar; los que temieron la incorporación de nueva población multirracial; o los sindicalistas contrarios a la entrada de mano de obra barata. Sin embargo estas voces se diluyeron ante el clamor popular en favor de la expansión ${ }^{56}$.

Finalmente, un elemento decisivo en todo este asunto fue la opinión pública norteamericana, que a fines del verano del 98 era, en su mayor parte, favorable a la anexión de Filipinas. Antes de tomar una decisión definitiva o de proclamar sus intenciones respecto a las islas, McKinley quiso tomarle calibrar el sentir de los ciudadanos. En un viaje intencionadamente multitudinario que realizó a comienzos del Otoño por el Medio Oeste, olvidó su habitual tono mesurado y pronunció ardientes discursos en favor de la expansión por el Extremo Oriente, defendiendo la actuación norteamericana en Filipinas y subrayando la oportunidades que aquel ámbito ofrecía a los Estados Unidos. Sus mensajes tuvieron una entusiasta acogida en la opinión pública y McKinley tomó buena nota de ello. El Presidente y numerosos miembros de su partido pensaron que ir en contra de esta opinión podría tener resultados políticos nefastos y hacer peligrar, incluso, las posibilidades republicanas en las próximas elecciones presidenciales 57 .

55 "The sentiment in the United States is almost universal that the people of the Philippines, whatever else is done, must be liberated from Spanish domination. In this sentiment the President fully concurs..." Telegram Mr. Hay to Mr. Day, 28 October 1898, 55th Congress, 3d Session, House of Representatives, Papers relating to the Foreign Relations of the United States, 1898, Washington, 1901. Frederick MERCK, Manifest Destinity and Mission in American History, New York, 1963. Richard HOFSTADTER, The Paranoid Style in American Politics. Cuba, Philippines and Manifest Destinity, New York, 1952.

56 Robert L. BEISNER, Twelve against Empire. The Anti-imperialists, 1898-1900, New York, McGraw-Hill Book Company, 1968.

57 Respecto a las motivaciones políticas detrás de las actuaciones del presidente McKinley es especialmente interesante la obra de John OFFNER, An Unwanted War. The Diplomacy of the United States and Spain over Cuba, 1895-1898, Chapel Hill, 1992.

R. I., 1998, n. $^{\circ} 213$ 
En esas circunstancias, McKinley, que desde el principio había apoyado la obtención de una base naval en Manila, decidió conscientemente, por motivos políticos, económicos, estratégicos e internacionales, anexionarse las Filipinas para defender los intereses americanos en el Pacífico, en China y en el Extremo Oriente, y en tal sentido trabajó durante la guerra hispano-norteamericana, hasta conseguir hacerse con aquellas islas a cambio de 255 millones de dólares en el Tratado de Paz de París, firmado con España el 10 de Diciembre de 1898.

De esta forma, se puede señalar, ya como conclusión, que en 1898 el Gobierno de los Estados Unidos reafirmó y asumió oficialmente la expansión ultramarina que los norteamericanos habían iniciado hacía muchas décadas y que se había ido incrementando con el paso del tiempo, aún sin el respaldo gubernamental. El Presidente McKinley adoptó una nueva política exterior, intensificando la participación norteamericana en la escena internacional. Y, en el caso que nos ocupa, apoyó la anexión de las Filipinas a los Estados Unidos.

En este proceso, la guerra hispano-norteamericana marcó un hito en la transformación de los Estados Unidos, porque supuso el comienzo del desarrollo de una nueva política mundial, su inclusión en el grupo de potencias que fijaban las directrices de la vida internacional, en la cual, y desde entonces, serían un interlocutor permanente. Significó también su irreversible implicación fuera de las fronteras continentales, la anexión de territorios extracontinentales, lo cual condujo al país a la construcción de un imperio colonial ultramarino. A convertirse, - parafraseando el título de un libro muy conocido de Leandro Prados ${ }^{58}$ - , de nación, en imperio ${ }^{59}$.

Durante la guerra, el Gobierno de McKinley fue quien decidió conscientemente la política a seguir, por motivos políticos, estratégicos, económicos, internacionales e ideológicos. No fueron las presiones exteriores, sino el propio convencimiento del Ejecutivo. Sin embargo, en el proceso, McKinley contó con el apoyo mayoritario de sus ciudadanos. En especial de círculos políticos republicanos, partidarios del engrandecimiento exterior de los Estados Unidos; de

58 Leandro Prados, De imperio a nación. Crecimiento y atraso económico en España, 1780-1930, Madrid, 1988.

$59 \mathrm{M}^{\mathrm{a}}$ Dolores ElizALDE, "De Nación a Imperio: la expansión de los Estados Unidos por el Pacífico durante la guerra hispano-norteamericana de 1898”, Hispania, n 196, 1997, pp. 551-588.

R. I., 1998, n. $^{\circ} 213$ 
estrategas y oficiales de marina; de determinados círculos de negocios que querían la apertura de nuevos mercados y áreas de inversión, el final de la inestabilidad en Cuba, y la expansión hacia el Pacífico y más concretamente hacia el mercado chino; de sectores religiosos y humanitarios que defendían el sentido de misión y deber de la extensión de los valores americanos sobre pueblos más atrasados. Y al final, también el apoyo mayoritario de una opinión pública, muy manipulada en su orientación, pero que con su respaldo a la política de McKinley, acabó de decidir la actuación del Presidente en la guerra y en las Filipinas.

The objective of this paper is to present an image of the Philippines at the end of the 19 th century, different to the picture of underveloped islands, inhabitated by savages unable to selfgovernment, transmited by the historiography and caricatures of that time. With this purpose, they are studied the process of redefinition of the Spanish colonial goverment, the strengthening of a new filipino society, the development of the economy and commerce, and the strong international interests in the islands. 